\title{
Specialized Prosecutor's Offices of Kuzbass in Regional Coal Mining and Environmental Safety Protection
}

\author{
Vitaly Shelestukov ${ }^{1, *}$, Vasili Erin ${ }^{2}$, and German Pavlov ${ }^{3}$, \\ ${ }^{1}$ Plekhanov Russian University of Economics (Kemerovsky branch). 650992, Kuznetsky avenue 39, \\ Kemerovo, Russia. \\ ${ }^{2}$ Kemerovo state university, 650000 , Krasnaya St. 6, Russia. \\ ${ }^{3}$ Plekhanov Russian University of Economics (Kemerovsky branch). 650992, Kuznetsky avenue 39, \\ Kemerovo, Russia.
}

\begin{abstract}
The increasing role of specialized prosecutor's offices on supervision of ecological and industrial (coal-mining) safety is considered in the article. The President of the Russian Federation approved a number of standards and legal documents confirming that the environmental problem had become a threat for national security of the state and society. Statistical data on inter-regional nature protection by prosecutor's office and prosecutor's office on supervision of obeying the laws in the coalmining industry are provided in the article. Specialized prosecutor's offices of the Kemerovo region actively participate in protection of the ecological rights and freedoms of citizens and the rights of employees of the coalmining enterprises for work in the conditions meeting the requirements of industrial safety. Special attention is paid to the supervision in the sphere of water, atmospheric air, forest exploitation, industrial and consumption waste legislations.
\end{abstract}

\section{Introduction}

The Constitution of the Russian Federation (Art. 42) provides each citizen with the right for the favorable environment. Reliable information about environmental conditions must also be provided as well as the compensation of damage caused to health or property by environmental accidents [1].

The standards of ecological and industrial safety provided earlier do not meet modern requirements. So this issue is of great importance today. The Governments in many countries constantly pay attention to these questions [2].

According to the Strategy of national security of the Russian Federation approved by the Decree of the Russian President from 31.12.2015 No. 683, environmental safety and rational environmental management are an integral part of national security. Strategic objectives of their provision are:

\footnotetext{
*Corresponding author: 2255@mail.ru
} 
- preservation and restoration of natural systems, ensuring quality of the environment necessary for human life and sustainable development of economy;

- elimination of ecological damage from economic activity in the conditions of the increasing economic activity and global climate changes.

According to section 84 of National Security Strategy, the factors exerting negative impact on ecological safety are «exhaustion» of deposits of mineral and raw materials, water and biological resources, inefficient and «injurious» environmental management, prevalence of the extracting and resource-intensive branches. The negative impact is also exerted by «the big specific weight of shadow economy, existence of ecologically unsuccessful territories characterized by high extent of pollution and degradation of natural complexes». The large damage to ecology is caused by numerous ecologically dangerous productions, the small number of capacities for protection of atmospheric air. In addition, there is insufficient purification of industrial and city sewage, low level of neutralization, utilization, placement and processing of municipal solid waste of consumption and production. All these and many other negative factors can be solved by acceptance and implementation of many measures for stimulating the introduction of innovative technologies, processing and recycling, construction and modernization of treatment facilities, etc. One of the main measures directed to counteracting the threats in the field of ecological safety is development of system of the governmental ecological supervision and control, monitoring of the environment, an animal and flora, land resources, ensuring compliance with sanitary and epidemiological standards concerning drinking water, soils, atmospheric air. [4]

The ecological situation in regions, especially in industrially developed ones, is a «bomb» of the slowed-down action. As the Russian President in the message to Federal Assembly said: "It is difficult to speak about long and healthy life if still millions of people are forced to drink water which doesn't meet standards, If the snow is black in Krasnoyarsk, and inhabitants of the large industrial centers like Cherepovets, Nizhny Tagil, Chelyabinsk, Novokuznetsk (it is allocated by the author) and in some other cities don't see the sun for weeks". [5] Only in the Kemerovo region more than 1.5 million tons of pollutants are emitted into the atmosphere each year and more than half a million cubic meters of dirty sewage is discharged into water bodies [6].

The Kemerovo region is one of the most developed industrial regions of Russia and at the same time, it is one of the most ecologically adverse. Regional coefficient at a rate of 1.3 was used in the Kemerovo region in the period of the USSR. Subsequently, in 2007 deputies of the Kemerovo city council proposed to increase regional coefficient to 1.5 [6], having explained it with severe climatic and ecological conditions. Unfortunately, this initiative has not been supported by the federal center yet.

\section{Material and Methods}

The supervision of obeying the laws in the sphere of environmental safety on conservation and rational use of resources is referred by the Order of the Attorney-General from July12, 2007 No. 195 "As public prosecutor's supervision of observing the laws and respect for the rights and freedoms of a person and a citizen is organized". [7] The order belongs to one of the priority directions of public prosecutor's supervision. Besides, the Order of the Prosecutor General's Office of the Russian Federation from May 5, 2008 No. 84 "About differentiation of prosecutors' competence of territorial, military and other specialized prosecutor's offices" has provided creation of specialized nature protection prosecutor's offices. [8] In the territory of the Kemerovo region the nature protection prosecutor's office exercises supervision of performance of the nature protection legislation by local governments, public organizations. In addition, nature protection prosecutor's 
office provides supervision over state bodies and controls the enterprises, institutions and the organizations of different types of the industry. The Kemerovo inter-regional nature protection prosecutor's office revealed 452 violations of the law, during implementation of supervision of performance of the legislation on conservation and rational use of the resources in 2017. More than 430 violations were revealed in the sphere of environmental protection. The number of the violations in public authorities of executive power was 158 , in commercial and other organizations there were 287 . The greatest number of the revealed violations (192) was the violations of water legislation and the legislation in the sphere of protection of atmospheric air. There were 125 violations in the field of forest exploitation. In order to eliminate the revealed violations, 12 submissions were made, 14 officials were brought to disciplinary responsibility. [6] The nature protection prosecutor's office devotes a special attention to verifying the implementation of legislation aimed at ensuring the safety of waste of 1 and 2 hazard classes. During the operations of a number of commercial organizations, the prosecutor's office found violations of the law related to the late payment of fees for the negative impact on the environment. Violations of the deadline for the declarations` submission on payment for negative impact on the environment, exceeding the norms for the waste formation of 1 and 2 hazard classes were also revealed.

The nature protection prosecutor's office also carried out inspections of performance of the legislation on veterinary. In the course of inspections in a number of areas, violations of veterinary and sanitary rules for collecting, disposing and destroying biological wastes were identified in the arrangement of anthrax burial sites in a number of areas. Infringements have appeared in an inadequate sanitary condition of objects. It did not exclude the possibility of free access for people and animals to the territory of biological waste burial.

Taking into account the large number of coal-mining and processing enterprises, as well as a significant number of accidents with fatalities and industrial injuries, Kemerovo inter-regional Prosecutor's Office for Supervising the Execution of Laws in the Coalmining Industry (with a Dislocation in Novokuznetsk) as part of the Kemerovo Region Prosecutor's Office was established. It was the request of the Governor of the Kemerovo Region in order to strengthen and improve the prosecutor's supervision by the order of the Prosecutor General of the Russian Federation on June 1, 2010. This unique department operates only in the territory of Kuzbass [9].

Taking into account the fact that Kemerovo region is one of the leaders in the field of coal mining, this prosecutor's office supervises the implementation of federal legislation by heads and officials of enterprises and organizations, related to the extraction and processing of coal. The prosecutor's office takes measures to protect the rights of citizens for safe working conditions, to prevent the occurrence of injuries and accidents at work, to eliminate the causes and conditions that contribute to them.

\section{Results and Discussions}

Strict implementation of laws in the sphere of forest exploitation, handling of industrial and consumption waste, attraction to disciplinary responsibility of officials for offenses also plays the leading role. In addition, the role of public organizations in fight for the ecological rights and freedoms of citizens is emphasized.

The prosecutor's office also oversees the activities of the controlling bodies to ensure their state control and supervision over compliance with the legislation in the field of labor protection and industrial safety, timely taking measures against managers and officials who committed violations of the law.

Among the main reasons for decreasing the fatal accidents at the enterprises of coal industry in total there are large-scale changes in standard and legal base for the last years. 
In confirmation of the mentioned above the number of accidents at the coal-mining enterprises for the last five years had been reduced twice, accidents with a lethal outcome had been cut in 9 times. [10]

The purpose of the prosecutor's office is to oversee the state of legality in the sphere of labor and industrial safety in the organizations of the coal mining industry, to achieve accident-free operation of hazardous production facilities through the implementation by the relevant subjects of the current legislation. It ensures effective interaction of control bodies, state authorities, local governments and other entities with a view to taking measures to protect the rights of citizens for safe working conditions, strict implementation of the organization and coal mining industry legislation on labor protection, excluding the possibility of accidents.

The most widespread violations of requirements of industrial safety at the enterprises of coal industry are in the area where there is a discrepancy of number of employees at the enterprises; violations of the rest and work schedule; violations of the decisions provided by the project documentation. Some other widespread violations are: absence or untimely carrying out certification of engineering staff; lack of examinations of industrial safety. The totality of these factors affects compliance with security requirements and deprives workers of the rights for safe working conditions guaranteed by the Constitution of the Russian Federation. The analysis of results of public prosecutor's checks confirms prevalence of violations of the law that testifies the necessity of strengthening the public prosecutor's supervision in this direction.

For example, economic entities in the Kemerovo, Chelyabinsk regions, the Republics of Buryatia, Komi and other regions of the Russian Federation often had not been examined of industrial safety in project documentations, technical devices, buildings and constructions. These enterprises operated on hazardous production facilities that violated the requirements of Article 9 of the Federal law from July 21, 1997 No. 116-FL "About industrial safety of hazardous production facilities".

Repeatedly the prosecutors elicited the facts of non-execution of own actions and decisions directed to prevention of accidents and incidents by the economic entities. For example, it was during the clarification of circumstances of the explosion, the event took place in one of mines in the Kemerovo region, which led to the loss of human life. It was established that many violations by technical officers of requirements to the organization and implementation of production control over observance the rules of industrial safety on hazardous production facility caused accidents.

Considering that 2017 was announced «Year of ecology » in Russia, the opened forum of Prosecutor's office of the Kemerovo region was devoted to the problems of ensuring the rights of citizens for the favorable environment. In particular, such questions as protection of atmospheric air, water objects and lands from pollution were considered at the forum. In addition, participants of the forum discussed the problems of compulsion for the enterprises to build clearing constructions, installation of dust removal equipment, facts of illegal preparation of wood. Especially it is necessary to pay attention to the issues of indemnification because of placement the production wastes on the land plots. Therefore, for the first four months 2017, bodies of prosecutor's office in the Kemerovo region revealed more than four hundred violations of the law in this sphere. These violations were made by the local governments, as well as by the state supervision, and economic entities. For their elimination 103 prosecutor's acts (representations) were brought, 13 claims were sent to the court. Upon the demand of prosecutors, courts passed 31 decisions on elimination of unauthorized dumps by the local governments in 2017-2018. In 201745 dumps were revealed, measures were taken for their elimination.

\section{Conclusion}


The necessity to solve the environmental problems which have become a threat to the national security of the state and society appears to be acute in the country. The analysis of statistical data confirms the growing role of specialized prosecutors of the Kemerovo region. The work of specialized prosecutors is impossible without the involvement and support of the public and the theoretical developments of the scientific community of the region.

\section{References}

1. The Constitution of Russian Federation of 12.12.1993 (Law Office, Moscow, 1993)

2. S. Anyona, B.K. Rop, Economics and Innovation Management, 1, 17-29 (2017) DOI: 10.26730/2587-5574-2017-1-17-29

3. The Decree of the President of the Russian Federation of December 31, 2015 No 683 "On the Strategy of National Security of the Russian Federation" (Law Office, Moscow, 2015)

4. Tyulenev, M., Zhironkin, S., Kolotov, K., Garina, E., Poll. Res. 35:2, 221-227 (2016)

5. N. N. Golofastova, V. G. Mikhailov, I. V., Seredyuk I.V. Economics and Innovation Management, 1, 66-75 (2017) DOI: 10.26730/2587-5574-2017-1-66-75

6. V. G. Mikhailov, Ya. S. Mikhailova, Economics and Innovation Management, 3, 73-79 (2017) DOI: 10.26730/2587-5574-2017-3-73-79

7. Order of the Prosecutor General's Office of Russia from 07.12.2007 No. 195 (as amended on 01.07.2015) “On the organization of prosecutor's supervision over the execution of laws, observance of human and citizen's rights and freedoms" (Law Office, Moscow, 2007)

8. Order of the Prosecutor General of Russia from 07.05.2008 № 84 (Edited on 02.07.2015) "On the delineation of the competence of prosecutors of territorial, military and other specialized prosecutor's offices" (Law Office, Moscow, 2008)

9. V. N. Shelestukov, Black Holes in the Russian Legislation, 3, 114-121 (2016)

10. J. Janočko, M. Cehlár, Z. Šimková, Economics and Innovation Management, 3, 32-45 (2017) DOI: 10.26730/2587-5574-2017-3-32-45 